\title{
Anthós
}

$5-2020$

\section{Snowfall on Orhan Pamuk's Literary Canvas}

Jane Eden Hartle

Portland State University

Follow this and additional works at: https://pdxscholar.library.pdx.edu/anthos

Part of the Modern Literature Commons

Let us know how access to this document benefits you.

\section{Recommended Citation}

Hartle, Jane Eden (2020) "Snowfall on Orhan Pamuk's Literary Canvas," Anthós: Vol. 9: Iss. 1, Article 4. https://doi.org/10.15760/anthos.2020.9.1.4

This open access Article is distributed under the terms of the Creative Commons Attribution-NonCommercialShareAlike 4.0 International License (CC BY-NC-SA 4.0). All documents in PDXScholar should meet accessibility standards. If we can make this document more accessible to you, contact our team. 


\section{Snowfall on Orhan Pamuk's Literary Canvas}

Jane Eden Hartle

\section{Introduction}

In his memoir Istanbul: Memories and the City, Orhan Pamuk writes that during his childhood, it snowed an average of only five days per year with the snowfall lasting on the ground for a week to ten days (Pamuk 2006). And yet, throughout the novels Snow (2002), The Black Book (1990), and My Name is Red (1998), the snow falls fairly consistently as the plots unfold, blanketing the town roads and city streets, muffling sounds, and both revealing and obscuring all that it covers. The following paper, which grew out of a seminar project on Pamuk's The Black Book, My Name Is Red, Snow and Istanbul: Memories of a City, explicates the author's use of snow as a symbol. In these works snowfall simultaneously covers and exposes historical, cultural and political content.

Pamuk uses snowfall the way an artist would use paint. As a backdrop, it sets the stage for all the events that take place within it. At different times, snow blurs and defines social and individual borders, covers some things up and makes others stand out. Snow hides and announces, shelters and exposes the objects upon which it falls-- the orthodox believer, the amnesiac writer, or the blinded painter. It appears not just in Pamuk's novel by the same title, but also in his two other novels and the memoir examined here. Throughout these literary works, Pamuk's use of snowfall stands out as intentional; a way in which the author invites readers to engage in the creative process by registering different meanings. This essay will explore some of the topics which Pamuk illustrates with snow, presenting examples of the different ways snow is used to symbolize larger themes and ideas. 


\section{Snowfall in Snow}

Snow takes place in the forlorn Eastern Turkish city of Kars, caught in a violent dispute between two orthodoxies-- stringent secularism and Muslim fundamentalism during the 1990s. The novel is told from multiple perspectives. The protagonist, a poet known as $\mathrm{Ka}$, is presented with different, often conflicting angles of the same story. Characters from what appears to be a clash of cultures within one society attempt to draw Ka's favor. In the end, the reader is handed the evidence and then left to make up their own mind about what to believe.

In Snow, the symbolism of snow is first presented as a literal barrier from movement caused by a winter storm. The book's events only are able to take place because a blizzard causes the roads in and out of Kars to become temporarily unusable, creating a microcosm; a reflection of Turkey's socio-political conflict on a smaller and more immediate scale, a snowglobe shaken violently by outside forces. The encompassing silence of snow relates directly to the themes of political censorship that are prevalent throughout the works examined here. The falling snow, which blankets and obscures all that it falls upon, is reminiscent of the modern state of Turkey's determination to cover the atrocities of the past by forbidding their discussion. In the article "Beyond Secularism: Orhan Pamuk's Snow and the Contestation of 'Turkish Identity' in the Borderland," Ülker Gökberk argues that the portrayal of Kars in Snow as a snow-covered ghost town is designed to be a metaphor for marginalization and erasure. "The notion of a cohesive and homogenous 'Turkish identity' was created by the erasure of ethnic, cultural, and linguistic diversity that once defined the region," Gökberk claims, referencing the deportations and massacres of the Armenian people (Gökberk, p.7). She goes on to discuss the significance of the icicles that Ka observes as looking "like ghosts" beneath the "deathly glow" of the streetlamps. This imagery, Gökberk argues, is a specific and intentional 
reference mourning the tragic loss of Armenian culture in the area in which Snow takes place (Gökberk p.7).

The subject of covering is also not exclusive to falling snow, as the use of headscarves to cover hair and preserve privacy and virtue is a fiercely debated topic throughout the book. The parallel between these two metaphors is made explicit; the snow is often described as "cloaking" or "veiling" what is under it, language that relates specifically to these religious garments. Like the scarves, to Ka the snow both signals purity and hides darkness: "Veiling as it did the dirt, the mud, and the darkness, the snow would continue to speak to Ka of purity" (Pamuk 2002).

In Snow, the protagonist is a writer who returns to his home country after being forced into exile over a political statement. This element of Snow, a book which itself discusses scenes described in fiction coming true after the fact ("Writing the news before it happens," the characters call it) eerily foreshadows the events of 2005, several years after Snow's 2002 publication, when Pamuk was tried for "Insulting Turkishness" after his public references to the Armenian genocide. Although the trial was later halted on a technicality, various Turkish newspapers launched book burnings and hate campaigns against Pamuk, with some outspoken columnists calling for the author to be "silenced for good" (Pamuk 2005). Pamuk, who had his first encounter with censorship in 1995 alongside a group of other writers after denouncing the state's treatment of the Kurdish minority and political dissidents, was forced to flee his beloved Istanbul. In an editorial article for the New Yorker Magazine, Pamuk discussed the situation and its impact on his own identity - the uneasiness he felt at finding himself "caught between my country and the rest of the world" (Pamuk 2005). This identity conflict, on both a personal and a national level, is another recurring theme throughout the novels, which is again symbolized in Pamuk's works of fiction by the falling of snow. 
In Snow, it is a fictional Orhan, the childhood friend of Ka, retracing Ka's steps after his death, who comments on the "less poetic snowfall"-- one that melts upon contact with the muddy pavement in the city of Kars that he views out the window of the hotel where his friend once lived, drank raki, and wrote poems (Pamuk 2005). The absence of white snow accumulating in Kars upon Orhan's visit to the city is a visual representation of how things have changed, and how life has gone on moving forward, just as Ka predicted it would: "As soon as the snow melted everything would go back to normal," Ka says to Kadife, (Pamuk 2005). Indeed, the storm settled and the snow began to melt, freeing Kars from its covering of frozen stillness and isolation, and Ka returned to Germany.

\section{Snowfall in The Black Book}

In The Black Book, which was first published in Turkish in 1990, twelve years before Snow's publication, readers must again assemble a narrative told from two perspectives, as the line between them grows increasingly unclear. The book's hero, Galip, struggles to make sense of his wife's absence as his own identity fragments.

Throughout the book, the snow serves as a blank canvas. The expansive whiteness and emptiness of the snow-covered ground creates open space for the characters to inhabit. This symbolism is especially visible through the story of the prince illustrated in one of the many excursions into Turkish history that enrich The Black Book, a character who seeks his own uninfluenced identity by enclosing himself in a featureless room. Likewise, Galip finds himself night after night walking alone through the snow. This prince sought whiteness, blankness, hoping to learn about himself, but instead learned that by covering up all other voices he loses his own as well, and becomes lonely and irritable. Galip, whose private identity crisis has shaken his self-concept almost into nonexistence seems to recreate this scene, hoping to find his true self alone in the snow-cloaked empty streets, and night after night, finding nothing. The characters learn that one's 
identity is formed not in a colorless expanse but through connections with others, and with one's culture and history.

The loss of one's connection to their culture and its history is discussed on a micro, personal level, as the newspaper columnist Celal's memory is buried beneath the snow of his mind. Celal's former coworker tells Galip, "It's not just his memory Celal Bey has lost, it's his past — and this was his last link with his country" (Pamuk 2006.) The connection Pamuk makes between snowfall and the obscuring of the past is strengthened by the epigraph he uses for chapter nine: "Sometimes snow fell, and sometimes darkness," (Pamuk, quoting Sheikh Galip 2006).

\section{Snowfall in My Name is Red}

Published in Turkish in 1998, Pamuk's novel My Name Is Red is a murder mystery that unfolds in the sixteenth century as a group of Turkish painters grapple with the artistic and cultural effects of the Venetian Renaissance. Readers must again weave the plot together from fragments, with each character -animate or inanimate-- narrating from their own point of view. The protagonist, Black, attempts to fit these vignettes together alongside the reader to catch the murderer, and win the heart of the woman he loves.

Falling snow, which at the same time highlights and hides from view all that it blankets, is used to paint the conflict and duality between revealing and obscuring Turkish culture and history. In My Name Is Red this theme is central to the plot of the book. The threat to the purity and integrity of Turkish culture is perceived to come from outside, as the influence of the Venetian Renaissance threatens to disrupt the characters' notions of tradition. As the snow sweeps across the streets of Istanbul, some of the miniaturist painters adopt different styles of artwork with guilty fascination, borrowing elements of style from the European painters to combine with their traditional Turkish techniques.

Throughout the book, Pamuk draws on the use of color to engender emotional responses. The whiteness of the falling snow portrays piety, virtue, 
and freedom from influence. The snow stands in for youthful or forgotten innocence or purity; the covering of darkness and sin, and things remaining as they once were. There are other instances which further strengthen this connection between white snow and the divine: after taking his own vision, an act which in his mind has spared him from the impurity of looking upon an increasingly sinful world, Master Osman is described as "gazing at a distant, unattainable whiteness" (Pamuk 2002). This link is evidenced again by the comments made by Shekure's younger son in the same novel, another fictional Orhan, who says, "Everything was covered in snow. It was as if nothing had changed at all" (Pamuk 2002). This reinforces the symbolic connection between snow and covering up the past, freezing things as they are, and protecting them from movement and change.

\section{Snowfall in Istanbul: Memories and the City}

Published in 2006, after Snow, The Black Book, and My Name Is Red, Orhan Pamuk's work of nonfiction, Istanbul: Memories and the City is not told linearly; instead it drifts from Turkish history to discussions of the numerous literary works that have shaped and described Istanbul throughout the years, to personal anecdotes about growing up in a changing world.

Like his protagonists, Pamuk finds his own identity revealed to him in the falling snow. In Snow, Ka, his childish heart full of poetry and hope, sees beauty in the plump snowflakes drifting lazily down from above; the unnamed murderer in My Name Is Red sees only sorrow, and in The Black Book, formless Galip looks upon these same streets and finds nothing but a great emptiness. Likewise, in his memoir Pamuk describes looking out into the snow-cloaked cobblestone roads of Istanbul and seeing a beautiful, overwhelming melancholy, and feeling a deep sense of fellowship with the people rushing through the darkening streets.

This snow, which Pamuk describes as "blanketing his childhood" both made the city look new and transformed it into something like the black and white 
scenes of the old movies and architectural drawings he found so fascinating. "To see the city in black and white is to see it through the tarnish of history," Pamuk writes, adding that the snowy days were the ones where he felt closest to the city's "fabulous past" (Pamuk 2006). The snow reveals this connection, but at the same time covers it. "The snow made the city look new," Pamuk writes, "Not only by covering up the mud, the filth, the ruins, and the neglect, but by producing in every street and every view an element of surprise, a delicious air of impending disaster" (Pamuk 2006). Pamuk describes the snowy winter evenings as "safe; the shameful poverty of our city is cloaked from Western eyes" (Pamuk 2006).

Perhaps in Pamuk's mind, the use of snow as a metaphor for simultaneously covering and revealing was born in these moments, as he faced a crossroads in his own life. Not yet a writer, torn between his desire to be an artist and the expectations and rigid cultural norms imposed upon him by his family and his country, Pamuk struggled to define his identity. The snowy Istanbul painted in Pamuk's memoir exists at the junction between modern and traditional, old and new, East and West, covered and uncovered. It seems only fitting for Istanbul, a city split down the middle by the Bosphorus Strait, to attempt to reconcile two equally powerful, often contradictory, but ultimately interdependent beliefs. This same duality and identity conflict is reproduced on an individual level within Pamuk as he ponders his destiny as a young artist, looking back at the past and forward into an unknown (snow-covered) future.

\section{Orhan Pamuk's Literary Canvas}

In the final chapters of Snow, the poems that were so crucial, so fundamental to the development of the plot and to Ka's identity are nowhere to be found. It is these missing poems that drew the character Orhan to the city of Kars but upon getting there, he finds they have vanished with the melting snow. The quest that led Orhan to retrace the steps of his late childhood friend remains unfinished; incomplete. The narrator shares two clues as to what these poems may 
have contained. One is the diagram of a snowflake that serves as a map of Ka's identity. Like the literary works discussed in this essay, it is a painting formed from fragments, an assembly of unique pieces put together to make a larger whole. The other clue we are left with is the appendix at the end of the book, titled "The order in which Ka wrote his poems," which displays the title of each poem alongside the corresponding page and chapter numbers in the book. It invites the readers to continue the quest, to follow in the footprints of Orhan, who followed Ka into the snow. We don't get definitive answers. They are not there. The absence of the poems is thus marked and made visible by snow, and the readers' awareness of absence defines their engagement with the work.

The explanations of the symbolism of snow that this essay covers are not a complete list, and it would be incongruous with the spirit of these works to present them as the only correct options. This characteristic ambiguity and openness to interpretation is part of what makes the works of Orhan Pamuk so enchanting. The reader cannot simply observe from a distance. We too stand at the crossroads, involved in the narratives. These books demand attention and interpretation, and in return we are given a chance to look out into the snowfall and decide what to make of these pages.

Like Galip, left searching through the forgotten fragments of Celal's half-finished columns, or Black following the clues hidden within the sacred pages of the forbidden book of paintings, or Orhan trying to piece together Ka's journey from the scribbled notes he left behind, in the end we can only offer our own interpretation, and find meaning for ourselves. 


\section{References}

Gökberk, Ü. (2008). “Beyond Secularism: Orhan Pamuk's Snow, and the Contestation of 'Turkish Identity' in the Borderland." Konturen, I. https://doi.org/10.5399/uo/konturen.1.1.1286. Accessed March 2020.

Pamuk, O. (2002). My Name Is Red. Translated by Erdag Goknar. London: Faber.

Pamuk, O. (2004). Snow. Translated by Maureen Freely. New York: Vintage International.

Pamuk, O. (2006). Istanbul: Memories and the City. Translated by Maureen Freely. New York: Vintage International.

Pamuk, O. (2006). The Black Book. Translated by Maureen Freely. London: Faber.

Pamuk, O. (December, 2005). On trial. The New Yorker Magazine. https://www.newyorker.com/magazine/2005/12/19/on-trial. Accessed March 2020. 